\title{
Who Actually Profits From Pulmonary Metastasectomy Operation? Retrospective Analysis of 12 Years
}

\author{
Serdar Evman ${ }^{1}$, Recep Demirhan², Ersin Çardak², Kadir Burak Özer
}

${ }^{1}$ Department of Thoracic Surgery, Süreyyapaşa Chest Diseases Training and Research Hospital, İstanbul ${ }^{2}$ Department of Thoracic Surgery, Kartal Lütfi Kırdar Training and Research Hospital, İstanbul

\begin{abstract}
Objective: Evaluating the benefits of metastasectomy and the possible prognostic factors associated with overall survival after surgical treatment.

Methods: Between January 2000 and January 2012, 148 pulmonary metastasectomy operations were performed on 126 patients (78 males, 48 females), with a median age of 32 . Data were examined retrospectively for age, gender, primary tumor histology, number of lesions, operative techniques, resection margins, mediastinal lymph node involvement, time to metastasis, and additional therapies. Effects of possible prognostic factors on 2-year and 5-year survival were then evaluated.

Results: Most patients (84\%) were asymptomatic; 126 patients underwent 148 metastasectomy operations. Definitive pathology revealed sarcoma in 63 (50\%), epithelial tumor in 58 (46\%), and melanoma in $5(4 \%)$. Complete resection (R0) was achieved in all patients. Average postoperative hospital length of stay was 5.4 (range: 2-8) days. Morbidity was $6.3 \%$, and 30 -day mortality was $1.6 \%$. Median overall survivals were found to be 42,27 , and 11 months ( $p=0.029$ ), with median disease-free intervals of 32, 21, and 7 months for epithelial tumors, sarcomas, and melanomas, respectively $(\mathrm{p}<0.001)$. The median survival of patients with single, 2 to 3 , and $4+$ metastatic nodules was 30,18 , and 15 months, respectively $(p=0.012)$. Median survival of patients with a disease-free interval of less than 12 months was 16 versus 30 months in those with an interval of more than 12 months $(\mathrm{p}=0.003)$. Additional mediastinal lymph node involvement was directly correlated with a worse outcome $(p=0.044)$.
\end{abstract}

Conclusion: Pulmonary metastasectomy is a safe and effective choice of treatment. Univariate analyses verified that histopathology of the tumor, disease-free interval, number of metastatic lesions, and lymph node involvement were significant prognostic factors in patients undergoing pulmonary metastasectomy.

Keywords: Lung metastases, pulmonary metastasectomy, secondary neoplasm, surgery, survival analysis

\section{Özet}

Amaç: Bu makalede, pulmoner metastazektomilerin sağkalıma olan katkısı ve sağkalıma etki eden diğer prognostik faktörler araştıııldı.

Yöntemler: Ocak 2000 - Ocak 2012 tarihleri arasında 126 hastaya 148 pulmoner metastazektomi uygulandı. Hastaların 78'i erkek, 48 'u kadın olup ortalama yaş 32 idi. Hastalar yaş, cinsiyet, primer tümör histolojisi, lezyon sayısı, ameliyat teknikleri, komplet ve inkomplet rezeksiyon saylları, mediasten lenf nodu tutulumu, hastalıksız yaşam süreleri ve ek tedavi yönünden incelendi. Prognostik faktörlerin iki ve beş yıllık sağkalım üzerine etkileri değerlendirildi.

Bulgular: Hastaların çoğunluğu (\%84) asemptomatik idi. 126 hastaya 148 cerrahi girisim uygulandi. Olgularin 63'unde (\%50) sarkom, 58 'inde (\%46) epitelyal tümör ve 5'inde (\%4) melanom metastazı saptandı ve tümünde komplet (R0) rezeksiyon gerçekleştirildi. Ameliyat sonrası ortalama hastanede kalış süresi 5,4 (2-8) gün, morbidite oranı $\% 6,3$, mortalite oranı \%1,6 idi. Epitelyal tümörler, sarkomlar ve melanomlar için ortanca sürvi 42, 27 ve 11 ay ( $p=0,029)$; hastalıksız yaşam süreleri ise 32,21 ve 7 ay olarak saptandi $(p<0,001)$. Soliter metastazlı hastaların ortanca sürvisi 30 ay iken, 2-3 metastatik lezyon bulunanların 18 ay, 4 ve daha fazla metastaz mevcut hastaların ise 15 ay olarak bulunmuştur $(p=0,012)$. Primer malignite tanısı ile metastaz ortaya ç1kışı arasındaki hastalıksız geçen süre 12 aydan kısa olanlar hastaların, 12 aydan daha sonra metastaz ortaya çıan hastalara göre sürvilerinin anlamlı olarak daha düşük olduğu da gözlenmiştir (16/30 ay, $\mathrm{p}=0,003)$. Mediastinal lenf nodu tutulumu da, bağımsız bir kötü prognostik faktör olarak bulunmuştur $(\mathrm{p}=0,044)$.

Sonuç: Pulmoner metastazların cerrahi rezeksiyonu güvenli ve efektif bir tedavi şeklidir. Tümörlerin histopatolojisi, hastalıksız yaşam süresi, metastaz sayısı ve mediastinal lenf nodu tutulumu önemli prognostik göstergeler olarak bulunmuştur.

Anahtar Kelimeler: Akciğer metastazları, cerrahi, pulmoner metastazektomi, sağkalım analizi, sekonder neoplazm
Received Date / Alındığı Tarih: 16.04.2014 Accepted Date / Kabul Tarihi: 02.08.2014 Available Online Date /

Çevrimiçi Yayın Tarihi: 25.11.2014

Address for correspondence / Yazışma Adresi Serdar Evman, Süreyyapaşa Gögüs Hastalıkları Eğitim ve Araştırma Hastanesi, Göğüs Cerrahisi Kliniği, İstanbul, Türkiye

E-mail / E-posta: sevman13@yahoo.com

(C) Copyright 2014 Turkish Respiratory Society (TRS) Eurasian J Pulmonol 2014

DOI: $10.5152 /$ ejp.2014.33602

- Available online at www.eurasianjpulmonol.com

\section{INTRODUCTION}

Despite efficient medical and local surgical treatment, primary organ malignancies frequently metastasize. In postmortem studies, it has been shown that more than $30 \%$ of cancer patients with an extrathoracic origin have concomitant pulmonary metastases, and a few have sole lung involvement (1).

Distant malignancy metastases detected in the lung are responsible for less than $5 \%$ of all pulmonary neoplasms (2). Until the first half of the $20^{\text {th }}$ century, pulmonary metastases were seen almost in $30 \%$ of patients, considered as an incurable malignant disease, and therefore, surgery had no place in the treatment modalities. After the 1960s, surgical resection had become a standard treatment of choice, performed with low mortality and morbidity, in selected patient groups with precise indications (3). Although surgical resection and/or radiotherapy may achieve local control of the primary tumor, the 
optimal treatment of choice for systemic metastases is still controversial. Patients with just pulmonary metastases have more therapeutic options than those with multiorgan metastases and respond much better to local and systemic treatments, resulting in prolonged postoperative 5 -year survival rates as high as $40 \%$ to $50 \%(1,3)$. There are no prospective and randomized trials on the efficacy of pulmonary metastasectomy (PM) in the literature, but this method is still being used with increasing popularity, just because of general conviction (3). In this study, the prognostic factors and role of metastasectomy operation in metastatic pulmonary lesions are presented, and we assessed whether all patients profit to the same degree or not, in light of recent data in the literature, with regards to our 12-year experience.

\section{METHODS}

\section{Patient Selection}

All patients undergoing PM between January 2000 and January 2012 in a single thoracic surgery clinic for lung metastasis of various primary malignancies were the cohort of the study. After retrieval of written consent, preoperative postero-anterior chest X-ray and thorax computed tomography (CT) examinations were used routinely for acquiring the most recent nodule count and distribution. The majority of patients was admitted to our clinic from the oncology department, with complete systemic screening for the presence of any extra-thoracic malignancy. The rest of the patients were screened for distant metastasis by a combination of cranial CT with abdominal ultrasonography and bone scintigraphy or since 2005 with positron emission tomography/computed tomography (PET/CT)

The standard criteria for PM indications mentioned in the literature were accepted: 1) the patient must be low risk for surgical intervention, 2) the primary malignancy site is under control, 3) there is no additional extra-thoracic metastasis, and 4) all of the lesions are resectable.

Patients who were unsuitable for PM according to the criteria above were not included in the study. Additionally, patients with recurrent PM or who had undergone PM despite an additional solitary cranial or suprarenal metastasis were excluded, as well.

\section{Investigated Variables}

Medical files, operational details, and final pathology reports after primary and PM operations of the patients were examined retrospectively. Primary endpoints of the study were tumor recurrence or the death of the patient. Data were classified and analyzed for age, gender, primary tumor histology, surgical approach and operation method, metastatic nodule count, mediastinal lymph node involvement, complete/incomplete resection, disease-free interval (DFI), and additional treatments (chemo- and/or radiotherapy). All medical data were obtained from the institutional computer database, from the oncology department, during routine postoperative follow-ups, and/or by phone calls to patients/relatives. No patient was lost until the primary endpoints.

\section{Statistical Analysis}

The primary endpoint of the study was taken as the death of the patient or the appearance of another thoracic and/or extra-thoracic metastasis. DFI was defined as the time from the primary surgery for malignancy to the diagnosis of pulmonary metastasis. The time interval from the time of metastasectomy until the last follow-up or death was taken for calculating survival. Effects of several prognostic factors on 2-year and 5-year survival were evaluated by Cox regression hazard model multivariate analysis. Kaplan-Meier analysis was used to estimate the survival data, with log-rank test for univariate significance. For comparisons of categorical and continuous variables, $\mathrm{X}^{2}$, Fisher exact, or Mann-Whitney U-test was used, and data were given with range or $95 \%$ confidence interval $(\mathrm{Cl})$ values, where appropriate. All statistical analyses were completed using the Statistical Packages for the Social Sciences (SPSS) software version 15.0 for Windows (IBM; Chicago, IL, USA). The maximum type I error was accepted as $5 \%$, and $p$ values $<0.05$ were considered to be statistically significant.

\section{RESULTS}

A total of 148 patients were operated on during the period described; 17 patients with a previous PM operation and 2 patients with preoperatively treated solitary cranial metastasis were excluded, and 3 patients had concomitant suprarenal solitary nodules and were also excluded from the study. The remaining 126 patients (48 females, 78 males) underwent 148 interventions and constituted the cohort of our inquiry. Only 20 (16\%) of the patients were symptomatic: dyspnea was present in 10, cough was present in 7 , and chest pain was present in 3.

The most common surgical approach used was posterolateral thoracotomy (64\%; $n=95)$. Median sternotomy was preferred in 10 (7\%) operations, video-assisted thoracoscopic surgery (VATS) was preferred in $13(9 \%)$, and bilateral staged thoracotomy was preferred in 30 (20\%). Sequential bilateral metastasectomy procedures were counted as a single operation. Wedge resection was the most com-

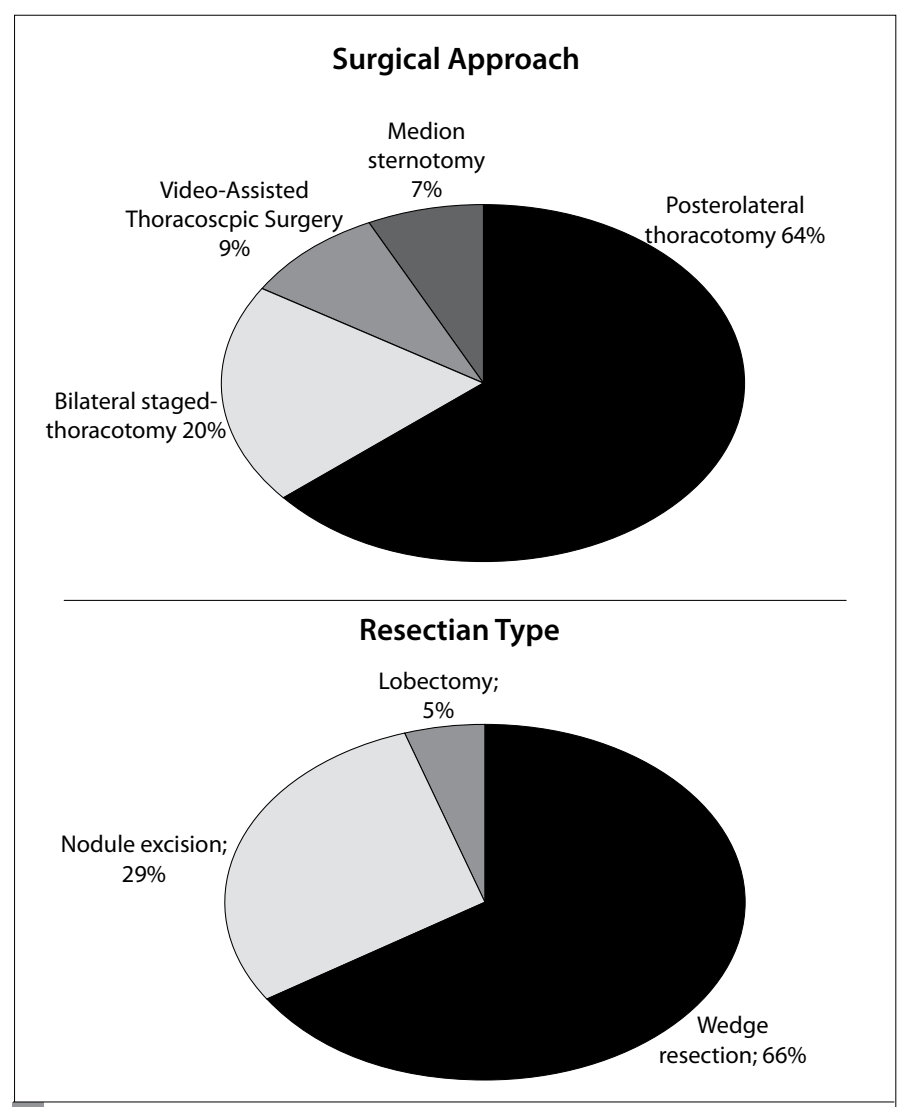

Figure 1. Distribution of surgical approaches and resection types (a), characteristics of different tumor types (b) 
mon type of resection, performed in $66 \%(n=97)$ of the patients. Nodule enucleation was sufficient in $43(29 \%)$, where 8 patients $(5 \%)$ underwent lobectomy. The distribution of surgical approaches and resection types is shown in Figure 1.

The definite pathology report revealed sarcoma, epithelial tumor, and melanoma metastasis in 63, 58, and 5 patients, respectively. The histopathological distribution of the primary tumors is shown in Table 1. The 2-year and 5-year survival rates were $54 \%$ and $21 \%$ for epithelial tumors, in addition to $42 \%$ and $8 \%$ for sarcomas. None of the melanoma patients survived 2 years after the metastasectomy operation in our study. The median postoperative survival for epithelial tumors, sarcomas, and melanomas was 42, 27, and 11 months, respectively. In terms of survival, malignant melanoma patients seemed to have significantly worse survival after PM $(p<0.001)$. The median DFI was found to be 21 months in sarcomas, 32 months in epithelial tumors, and 7 months in melanomas $(p<0.001)$, revealing a significant difference between the groups (Figure 1b).

Further, 28 patients had a single nodule, 44 had 2 or 3 nodules, and 54 patients had 4 or more metastatic nodules removed. The maximum number of metastasis resected from a single patient was 16 . Pathologically confirmed solitary metastasis patients had a median survival time (MST) of 30 months (95\% Cl: 21.1-40.6), with 2-year and 5 -year survival rates of $54 \%$ and $18 \%$. Among the patients with 2 or 3 lesions, the MST was found to be 18 months (95\% Cl: 11.1-27.9), with 2-year and 5-year survival rates of $35 \%$ and $11 \%$. In patients with 4 or more metastatic lesions, the MST was 15 months ( $95 \% \mathrm{Cl}: 8.8-22.9$ ), with 30\% 2-year and 6\% 5-year survival rates (Table 2). These results confirmed a statistical difference in improved survival in the solitary metastasis group $(p=0.012)$.

Enlarged lymph nodes with suspicion of tumor invasion were dissected peroperatively, and $14 \%$ of the patients were found to have mediastinal lymph node involvement (N2). When compared with the non-involved group, the 2-year and 5-year survival rates were $28 \%$ and $0 \%$ to $54 \%$ and $12 \%$, with a significant enhancement of survival in favor of the No group ( $p=0.044$ ) (Table 2).
Patients undergoing PM with preoperative and/or postoperative additional therapy (chemo-/radiotherapy) had an insignificantly improved MST in our study. In patients with or without additional treatment, the 2 - and-5 year survival rates were $54 \%$ and $16 \%$ versus $25 \%$ and $4 \%(p=0.124)$.

When patients with single and multiple PM operations were compared in terms of survival, the 2-year and 5-year survival rates were 44\% and 16\% (median: 23 months) to 48\% and 29\% (median: 30

Tablo 1. Definitive histopathological diagnosis

\begin{tabular}{|l|c|c|}
\hline & $\mathbf{n}$ & $\%$ \\
\hline Sarcomas & 63 & 50 \\
Osteogenic sarcoma & 28 & 22 \\
\hline Malignant mesenchymal tumor & 20 & 16 \\
Ewing sarcoma & 5 & 4 \\
\hline Liposarcoma & 3 & 2 \\
\hline Leiomyosarcoma & 3 & 2 \\
\hline Synovial sarcoma & 2 & 2 \\
\hline Rhabdomyosarcoma & 2 & 2 \\
\hline Carcinomas & 58 & 46 \\
\hline Colon carcinoma & 31 & 24 \\
\hline Testis carcinoma & 9 & 7 \\
Breast carcinoma & 7 & 6 \\
\hline Renal cell carcinoma & 5 & 4 \\
Endometrial carcinoma & 3 & 2 \\
\hline Thyroid carcinoma & 2 & 2 \\
Choriocarcinoma & 1 & 1 \\
\hline Melanomas & 5 & 4 \\
\hline TOTAL & 126 & 100 \\
\hline
\end{tabular}

Tablo 2. Prognostic factors associated with overall survival

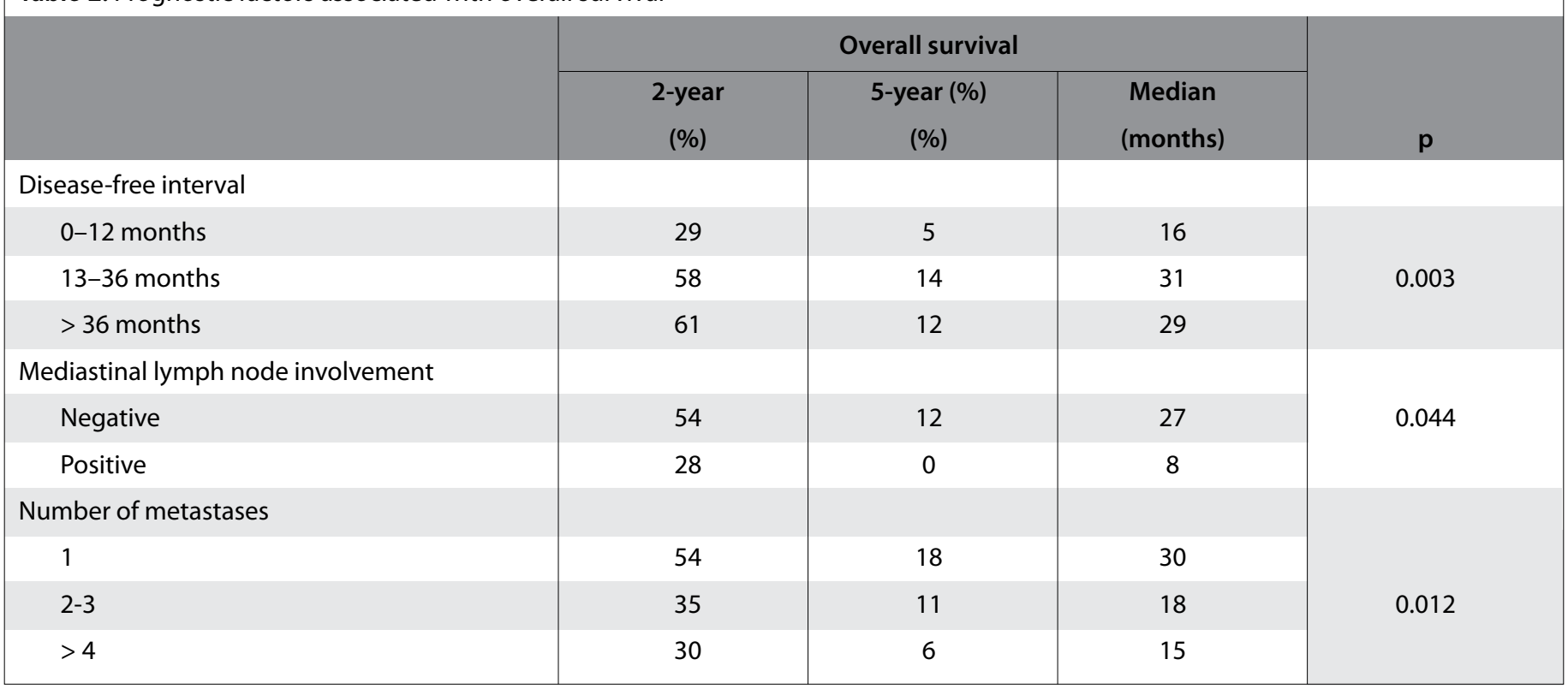


months), respectively $(p=0.082)$. Postoperative morbidity was seen in 8 patients $(6.3 \%)$, respiratory failure was seen in 4 , cardiac arrhythmia was seen in 2, and wound infection was seen in 2. Postoperative 30 -day mortality was $1.6 \%(n=2)$. The cause of fatality was myocardial infarction in 1 patient and respiratory deficiency in the other.

\section{DISCUSSION}

According to our findings, patients developing pulmonary metastases do not benefit much from PM operation in terms of postoperative overall survival if the histopathology of the primary tumor is a melanoma, if the DFI is shorter than 12 months, and if there are multiple metastatic nodules or mediastinal lymph node involvement present.

Distant metastases frequently occur in patients with malignant tumors and are indicators of progression of uncontrolled disease. Despite indicating systemic spread of the primary malignancy, the postoperative survival benefit of PM has been proven, and this procedure has been accepted as the treatment of choice in a select group of patients with distant metastases limited only to the lung parenchyma.

These metastatic nodules generally do not cause any symptoms and therefore are incidentally detected on routine follow-ups (2). Because of their subtle nature, they may be found on screening X-rays (CXR) or on the computed tomography (CT), which can be utilized for lesions obscured on CXR. In different studies of Treasure et al. (3), Kaifi et al. (4), and Monteiro et al.(5), the symptomatic patient rate was between $13 \%$ and $34 \%$. In our study, this rate was $16 \%$, consistent with the literature.

Lien et al. (6) detected pulmonary metastases in almost $50 \%$ of non-seminomatous testicular cancer patients, even with no evidence on routine CXR. Magnetic resonance imaging (MRI) has no regular use in detecting metastatic disease. It can only be useful in determining possible neural foramina, great vessel, or mediastinal invasion (7). In another study by Lucas et al. (8), the efficacy of 2-deoxy-2-[18F] fluoro-D-glucose (18F-FDG) positron emission tomography/computed tomography (PET/CT) was evaluated in detecting pulmonary metastases in 62 patients with soft tissue sarcoma. The result of their study revealed that its sensitivity was $86.7 \%$ and specificity was $100 \%$. In high-risk surgical patients, fine needle aspiration biopsy or a thoracoscopic lung biopsy can be considered for a definitive diagnosis before proceeding to the thoracotomy stage (9). With any suspicion of a possible nodule, thorax CT is used to verify the exact count and localization of the lesions. For scanning systemic metastases, PET/CT was performed on the last 36 patients of our cohort, instead of the combination of whole-body bone scintigraphy and abdominal CT. Our study revealed a $72 \%$ sensitivity and $80 \%$ specificity for PET/CT.

Many studies have been done in order to propound the possible prognostic factors of PM and thus distinguish a subgroup of patients who would benefit most from this operation. Histopathology of the primary tumor has always been thought of as the most important prognostic factor, after PM. In a large series of 5206 patients, Pastorino et al. declared that germ cell carcinomas have the best survival and melanomas have the worst survival after PM operation, indicating the importance of the primary tumor's histopathology, finding an MST of 40 months for epithelial tumors, 29 months for sarcomas, and 19 months for melanoma patients after PM; germ cell tumor patients with distinct prolonged survival (7). Liu et al. also found a
5 -year survival rate of $68 \%$ in germ cell carcinoma patients undergoing PM (9). In an additional study, 5- and 10-year survival rates for metastasectomy patients after epithelial tumors were reported as $47 \%$ and $38 \%$, respectively, with a mean survival of 61 months (5). After examining the results of 130 patients undergoing PM, Dilege et al. reported that soft tissue malignancy was the most common primary tumor in their PM group, and the average disease-free interval was 18.6 months (10). A review by Treasure et al. revealed that the 5 -year survival rate for sarcoma patients after lung metastasectomy was between $25 \%-34 \%$, which is still considered reasonable survival for a metastatic malignancy (11). These results, as well as ours, indicate the importance and efficacy of PM for patients with all different types of primary malignancies but melanoma.

The International Registry of Lung Metastasis has confirmed that the number of metastatic lesions, whether single or multiple, is a more precise prognostic factor for postoperative survival (7). Fewer nodules encountered peroperatively are associated with a better MST (3, 8). Five- and 10-year survival rates were found to be $43 \%$ and $31 \%$ in patients with solitary pulmonary metastasis, versus $27 \%$ and $19 \%$ in patients with 4 or more metastatic lesions, respectively (8). On the contrary, a few studies showed that there is no major correlation between the lesion count and survival $(5,11,12)$. The median survival of patients in our study with single, 2 to 3 , and $4+$ metastatic nodules was 30,18 , and 15 months, respectively ( $p=0.012)$, revealing a significant difference in overall survival periods between patients undergoing PM for single or multiple pulmonary metastases.

Mediastinal lymph node (N2) involvement is very rare in pulmonary metastatic lesions; however, it is definitely a negative prognostic factor for patients (13). None of our N2 patients survived 5 years after PM, regardless of their primary tumor. The survival of patients without metastatic lymphatic invasion of different malignancies was found to be approximately 6 -fold better than in those with the invasion, indicating the significance of systemic surgical lymphadenectomy in the accurate prediction of postoperative survival after PM (8).

It is not infrequent that patients with pulmonary metastatic lesions may develop other distant metastases; so, the fundamental of the treatment lies in the systemic control of the disease by radiotherapy and/or chemotherapy. Given the limited number of cases with a relatively short survival period, there are not many studies available for obtaining sufficient evidence on the advantage of these additional treatment modalities on postoperative overall survival. In only a few papers, it has been shown that chemotherapy, combined with surgical resection of the lesions, has a positive effect on postoperative survival for osteogenic sarcoma patients with solely pulmonary metastases $(3,14)$. Our results revealed a 3 - to 4 -fold improvement in 2- and 5-year survival rates of patients receiving additional therapies versus those without any postoperative therapy $(54 \%$ and $16 \%$ versus $25 \%$ and $4 \%$ ). Despite this big diversity, the difference did not reach the significance level $(p=0.124)$, probably due to the unbalanced and low patient distribution of the two groups for the necessary statistical tests.

Being a single-center retrospective study with a limited number of patients was the major limitation of our paper. DFI was taken as the time from the primary surgery and not the date of diagnosis of the primary malignancy, since the data were insufficient. In addition, 
different chemotherapy agents and regimens have been introduced within the last 12 years, which also may have caused a bias between the patients with the same pathology but different pre-/postoperative treatment courses. More homogeneous trials dealing with the same primary tumor groups and a sufficient number of cases are needed to reveal a more decisive result. Other additional factors, like patient performance status or co-morbidities, which may affect the prognosis, could also be investigated methodically.

\section{CONCLUSION}

In light of these findings, we can conclude that surgical resection of pulmonary metastases is a safe and potentially curative option of choice, as broadly accepted in the latest treatment guidelines, if performed with accurate indications. Type of primary tumor, extent of DFI, number of metastatic lesions, and mediastinal lymph node involvement were found to be significant prognostic factors determining postoperative survival in patients undergoing pulmonary metastasectomy.

\section{Ethics Committee Approval: N/A.}

Informed Consent: N/A.

Peer-review: Externally peer-reviewed.

Author contributions: Concept - R.D., E.Ç.; Design - S.E., R.D., E.Ç.; Supervision - R.D.; Resource - S.E., K.B.Ö.; Materials - S.E., R.D.; Data Collection\&/or Processing - S.E., E.Ç., K.B.Ö.; Analysis\&/or Interpretation - S.E.; Literature Search - S.E., K.B.Ö.; Writing - S.E., E.Ç.; Critical Reviews - S.E., R.D., E.Ç.

Conflict of Interest: No conflict of interest was declared by the authors.

Financial Disclosure: The authors declared that this study has received no financial support.

\section{REFERENCES}

1. Putnam JB. Secondary tumors of the lung. In: Shields TW, LoCicero J, Ponn RB; eds. General thoracic surgery. $5^{\text {th }}$ edition. Philadelphia: Lippincott Williams \& Wilkins; 2000.p.1555-76.

2. Shields TW. Pathology of carcinoma of the lung. In: Shields TW, LoCicero J, Ponn RB; eds. General thoracic surgery. Philadelphia: Lippincott Williams \& Wilkins; 2000.p.1235-68.
3. Treasure T, Milošević M, Fiorentino F, Macbeth F. Pulmonary metastasectomy: what is the practice and where is the evidence for effectiveness? Thorax 2014; Epub thoraxjnl-2013-204528.

4. Kaifi JT, Gusani NJ, Deshaies I, Kimchi ET, Reed MF, Mahraj RP, et al. Indications and approach to surgical resection of lung metastases. J Surg Oncol 2010; 102: 187-95. [CrossRef]

5. Monteiro A, Arce N, Bernardo J, Eugenio L, Antunes MJ. Surgical resection of lung metastases from epithelial tumors. Ann Thorac Surg 2004; 77: 431-7. [CrossRef]

6. Lien HH, Lindskold L, Fossa SD, Aass N. Computed tomography and conventional radiography in intrathoracic metastases from non-seminomatous testicular tumor. Acta Radiol 1988; 29: 547-9. [CrossRef]

7. Pastorino U, Buyse M, Friedel G, R. Ginsberg, P. Girard, P. Goldstraw, et al. Long-term results of lung metastasectomy: prognostic analyses based on 5206 cases. The international registry of lung metastases. J Thorac Cardiovasc Surg 1997; 113: 37-49. [CrossRef]

8. Lucas JD, O'Doherty MJ, Wong JC, Bingham JB, McKee PH, Fletcher CD, et al. Evaluation of fluorodeoxyglucose positron emission tomography in the management of soft-tissue sarcomas. J Bone Joint Surg Br 1998; 80: 441-7. [CrossRef]

9. Liu D, Abolhoda A, Burt ME, Martini N, Bains M, Downey R, et al. Pulmonary metastasectomy for testicular germ cell tumors: a 28-year experience. Ann Thorac Surg 1998; 66: 1709-14. [CrossRef]

10. Dilege S, Bayrak Y, Toker A, Tanju S, Kalaycı G. Metastatik Akciger Tümörlerinde Cerrahi Tedavi Sonuçlarimiz. Toraks Dernegi 5. Yıllık Kongresi, 24-27 Nisan 2002, Antalya.

11. Treasure T, Fiorentino F, Scarci M, Møller H, Utley M. Pulmonary metastasectomy for sarcoma: a systematic review of reported outcomes in the context of Thames Cancer Registry data. BMJ Open 2012; 2: e001736. [CrossRef]

12. Marina NM, Pratt CB, Rao BN, Shema SJ, Meyer WH. Improved prognosis of children with osteosarcoma metastatic to the lung(s) at the time of diagnosis. Cancer 1992; 70: 2722-7. [CrossRef]

13. Hamaji M, Cassivi SD, Shen KR, Allen MS, Nichols FC, Deschamps C, et al. Is lymph node dissection required in pulmonary metastasectomy for colorectal adenocarcinoma? Ann Thorac Surg 2012; 94: 1796-800. [CrossRef]

14. Mizuno T, Taniguchi $T$, Ishikawa $Y$, Kawaguchi $K$, Fukui $T$, Ishiguro $F$, et al. Pulmonary metastasectomy for osteogenic and soft tissue sarcoma: who really benefits from surgical treatment? Eur J Cardiothorac Surg 2013; 43: 795-9. [CrossRef] 